\title{
Author Meets Critics Panel: Paul B. Thompson's (2010) The Agrarian Vision: Sustainability and Environmental Ethics
}

\author{
Raymond Anthony
}

Published online: 7 September 2011

(C) Springer Science+Business Media B.V. 2011

The contributions below is the offspring of an Author Meets Critics panel that convened in June 2010 in Bloomington, IN, to discuss Paul B. Thompson's (2010) The Agrarian Vision: Sustainability and Environmental Ethics. Lexington: The University Press of Kentucky (ISBN 978-0-8131-2587-9). At the Agriculture, Food and Human Values: Food in Bloom, Erin McKenna, Lee McBride, Elisa Graffy and myself, were some of the first people to explore and critically examine publically with Professor Thompson some of the central tenets of his text. Paul Thompson-one of AFHV's founding members and past president-sheds light on the ways in which agrarian philosophies have significantly influenced discourses around both food and environmental ethics. The panelists discuss some of Thompson's central claims regarding the moral and ontological importance of eating together and the extent to which agrarian ideals can inculcate a much-needed ecological conscience as part of individual responsibility and virtuous citizenship in the twenty-first century. The Agrarian Vision captures a central living legacy of American thought and it promises to be an important resource for those interested in (re)examining and reforming agriculture. The intersection of agriculture and environmental ethics is particularly urgent in the wake of the current debate on sustainability, and since more mainstream or traditional forms of environmental ethics have proven to be impotent in dealing with the multidimensional realities around agriculture and food production. In The Agrarian Vision, Thompson astutely points out that American agriculture is caught between two competing ideals or "visions." One derives from the rough consensus on the industrial paradigm that emerged in the twentieth century. The alternative vision harks back to agriculture's past and is reinvigorated by Thompson to address conventional problems in agricultural, environmental, and food ethics. Agrarianism a la Thompson informs discussions around virtue theory, pragmatism, and contemporary philosophy of

R. Anthony (两)

Department of Philosophy, University of Alaska Anchorage,

3211 Providence Drive, Anchorage, AK 99508, USA

e-mail: ranthon1@uaa.alaska.edu 
technology. Thompson argues that agrarian philosophies can provide much needed symbolic, cultural, and moral functions to overcome the polarization prevalent in discourses on sustainability and contemporary food production. They also hold out promise for a truly ecological orientation to environmental philosophy.

Raymond Anthony

Session Co-organizer

Panel Participants

Author Meets Critics: Paul Thompson's Agrarian Vision (2010)

Raymond Anthony, The Ethics of Food for Tomorrow: On the Viability of Agrarianism-How Far can it Go? Comments on Paul Thompson's Agrarian Vision

Associate Professor of Philosophy

Department of Philosophy

University of Alaska Anchorage

Anchorage, AK 99508

Tel: 907.786 .4459

Email: ranthon1@uaa.alaska.edu

Elizabeth Graffy, Why Agrarian Philosophical Thought Matters for Sustainability Policy and Practice

Researcher

College of Agricultural and Life Sciences

University of Madison Wisconsin

101 Observatory Hill Office Bldg

1225 Observatory Dr

Madison, WI 53706

Tel: 608.235.4728 (cell)

Email: eagraffy@wisc.edu

Graffy was also served two decades in federal service with the Congressional Office of Technology, US Geological Survey and Department of Interior

Lee McBride, III, Agrarian Ideals and Practices: Comments on Paul B. Thompson's The Agrarian Vision

Assistant Professor of Philosophy

Department of Philosophy

The College of Wooster

Tel: 330.263.2548

Email: lmcbride@wooster.edu

Erin McKenna, Feminists and Farming: A Response to Paul Thompson's The Agrarian Vision

Professor of Philosophy

Department of Philosophy

Pacific Lutheran University

Tel: 253.535.7213

Email: mckenna@plu.edu 
Paul B. Thompson, Re-envisioning the Agrarian Ideal

WK Kellogg Professor of Agricultural, Food and Community Ethics

Department of Philosophy

Michigan State University

503 South Kedzie Hall

East Lansing MI 48824-1032

Tel: 517.355.4490

Email: thomp649@msu.edu 